\title{
Cultural Issues in English for Specific Business Purposes (ESBP)
}

\author{
Siti Mahripah ${ }^{1}$
}

\section{Fakultas Bahasa dan Seni Universitas Negeri Yogyakarta}

\begin{abstract}
ABSTRAK
Artikel ini menganut definisi budaya sebagai segala bentuk yang mengatur perilaku seseorang. Budaya umumnya bersifat abstrak dan dalam kehidupan sehari-hari dapat berwujud sebagai suatu nilai, norma, keyakinan, sikap ataupun perilaku. Budaya umumnya mewarnai setiap tindak komunikasi seseorang, termasuk juga dalam tindak komunikasi bisnis. Hal inilah yang mendasari mengapa Business English menarik untuk dikaji, karena dalam banyak kasus para pelaku bisnis umumnya memiliki latar belakang budaya - pola pikir, tata nilai, dan kepercayaan - yang tidak sama. Kendatipun demikian, mereka memiliki tujuan akhir komunikasi yang sama, yaitu melakukan transaksi bisnis. Implikasinya, dalam dunia bisnis Bahasa Inggris cenderung lebih banyak berfungsi sebagai media penghubung sehingga pengajaran Bahasa Inggris dalam konteks bisnis perlu untuk lebih ditekankan pada bagaimana seseorang dapat bersikap lebih fleksibel dan berkompromi dengan budayabudaya lain (dari lawan bisnis) sehingga dia dapat bertahan/survive dalam persaingan bisnis global yang sangat dinamis dan cenderung sulit untuk diprediksi. Dalam konteks ini, indikator kesuksesan komunikasi dalam Business English bukanlah terletak pada aspek keakuratan bahasa, melainkan pada bagaimana seseorang/pelaku bisnis dapat mengambil suatu posisi yang tepat dan strategis dalam melakukan dan menyelesaikan suatu transaksi bisnis. Kemunculan fenomena BELF (Business English as Lingua Franca) dan Glocal English merupakan hasil dari kontak budaya dalam dunia bisnis yang kemudian memberikan dampak pada dunia pengajaran, terutama pengajaran Bahasa Inggris yang menyangkut bidang bisnis untuk tujuan-tujuan khusus, sehingga pendekatan, teknik, metode, dan materi pengajarannya perlu mengakomodas keberadaan fenomena ini. Artike singkat ini akan membahas isu-isu budaya yang ada dalam lingkup ESBP (English for Specific Business Purposes): BELF, Glocal English, dan implikasinya dalam dunia pengajaran.
\end{abstract}

\section{Keywords: ESBP (English for Specific Business Purposes), BE (Business English), BELF (Business English as Lingua Franca), Glocal English, dan Pengajaran.}

\section{A. INTRODUCTION}

It is undeniable that nowadays English has become the most common language used across disciplinary areas and has widely been spoken across countries around the world. The fact that English serves as a media of communication used by people from different backgrounds raises some intercultural issues which most likely become concerns within English language teaching, particularly in ESP (English for specific purposes) area.

\footnotetext{
${ }^{1}$ Staf Pengajar Jurusan Pendidikan Bahasa Inggris Fakultas Bahasa dan Sastra Universitas Negeri Yogyakarta
} 


\section{JURNAL NOMINAL / VOLUME II NOMOR I / TAHUN 2013}

Culture is an integral part of the interaction between language and thought (Brown, 1992, p.89). Brown explains that cultural patterns, customs, and ways of life are expressed in language; culture-specific world views are reflected in language. This idea brings assumption that as people communicate, they will hold with them their indigenous culture values, beliefs, attitudes, and norms. These features are represented through the language they used as Bondi (2004, p.57) said that language brings one's cultural worlds into existence.

Nowadays there are an increasing number of interests towards studies in ESP areas, particularly related to the use of Business English (BE). This is apparently due to the globalization push which also happens to leap into the business setting in which multinational companies or joint-venture enterprises emerge rapidly around the world. To mention a few, those studies are for example, an extensive corpus based study of real-life BE and $\mathrm{BE}$ teaching (Nelson, 2000), an investigation of the consequences of introducing English as a corporate language for Finnish and Swedish employee in Scandinavia (Louhiala-Salminen, Charles, \& Kankaanranta, 2005), investigation of the Asian business discourse(s) (BargiellaChiappini, 2005); analysis of the language used in call centre industries (Warren, 2008), investigation of the English language use in localized business setting (Nair-Venugopal, 2008), and still many more. Drawing from the studies on business English mentioned above, it is found out that business discourse is less motivated by pedagogical concerns and more with a concern with understanding how people communicate strategically in an organizational context. This idea is also revealed by Bargiella-Chiappini et al. (2007)

In this paper, this short essay will attempt to discuss cultural issues within ESBP areas: English as lingua franca, glocal Englishes/world Englishes, and their implications in the ESBP teaching. The ESBP in this discussion is in essential addressed to the use of BE in a multiparty/multicultural business settings in which it is marked by the fact that most of the interactants are those of non-natives of English.

One needs to be careful in defining intercultural terms as it may give fuzziness borders, whether it relates to domain areas such as ethnicity, institutions, nationalities, race, or social community (Bondi, 2005). In this paper, a stance is taken to perceive culture from Condon definition (1973) as cited in Brown (1992) who says that culture is integrated patterns, most of which remain below the threshold of consciousness, yet all of which govern human behaviour just as surely as the manipulated strings of a puppet control its motion. Or in short, it is more as the representation of abstract entity people hold and believe which is realized in their day to day life as values, norms, beliefs, attitudes, and behaviour. 


\section{B. BUSINESS COMMUNICATION}

Business discourse is defined as all about how people communicate using talk or writing in commercial organizations in order to get their work done (Bargiella-Chiappini et al, 2007, p.3). Business communication is considered effective when the two interactants have a mutual intelligibility of what they are communicating at, regardless the inaccuracy of the linguistic features such as grammar and pronunciation. Hence, what they are mainly focusing during the communication is the end purpose which is the business affairs.

Communication within business setting varies across the types of businesses. However, there are some typicalities of genres that can be revealed. Nair-Venugopal (2008) listed some genres of language used in business communication such as advertisements, service encounters, and workplace interactions between co-workers, and in fact, she has done an extensive research in one of these areas, i.e. on the advertisement genre. While NairVenugopal mentioning about the types of genre, Planken and Nickerson (2009) have identified the types of English language functions which are used within the tangible situated business setting: English to tackle with conflictive setting such as negotiation, English to take parts in business meeting, and English to establish and maintain business relationships. Furthermore, Warren (2008) has studied functional English in a specific situated business institution for which he found that there is specificity in language moves and vocabulary in call centres.

As mentioned in the earlier part, that in every communication, including business communication, interlocutors seem to bring with them cultural identities they got from their native cultures, it is apparently seen that their business English communication is coloured by those cultures and hence marks the emergence of the intercultural business communication. It is quite interesting to look closely at how the $\mathrm{BE}$ is used within this setting where the interactants mostly do not share similarities of ways of thinking, valuing, and believing in things with their counterparts but they both have shared-common goals of business purposes at the end of the interaction.

Intercultural communication within ESBP framework seems to have operated in certain ways that it has distinctive characters compared to the other types of ESP areas. Many of the ESP practitioners mention that in most cases or situations in international business settings English is revealed as a lingua franca. In the ESP field, this emerged trend is called Business English as Lingua Franca (BELF). Another feature resulted from intercultural communication in business setting is the emergence of glocal English in which there is an 
adaptation of the English used in the local context. In both areas (either BELF or glocal English), cultural issues are almost becoming the hard core of the discussion which trigger or engender the acculturation phenomenon in business organizational context. This phenomenon is likely to be the result of compromise, rapport, cooperation, and relationship which usually become the marked strategies in maintaining business affairs.

\section{ENGLISH AS A LINGUA FRANCA IN BUSINESS DISCOURSE}

To succeed within the business discourse, people usually go to have training or learn through on-going experiences to achieve effective communication skills. Mastering these skills are quite essential, particularly in multinational or multicultural business enterprises where counterparts and co-workers are not sharing similar language and cultural backgrounds, and as a result English commonly turns out to be a lingua franca in this business discourse.

The use of BELF as an alternative tool of communication in multicultural business discourse often focus more on the successfulness of transferring the content message across the counterparts rather than on the English accuracy being used. Mutual intelligibility is often marked as accomplishment of the communication success.

The fact that business counterparts and co-workers are not English natives does not guarantee that the use of BELF is free from cultural bias or is cultural-neutral. Drawing from their research , Louhiala-Salminen et al. (2005) (cited in Planken \& Nickerson, 2009, p114-6) show that despite sharing a 'neutralizing' language, BELF speakers will continue to bring to business interactions 'their own culture-bound views of how encounters should be conducted', as well as 'discourse practices' inspired by their respective first language. In short it can be said that BELF is rather to be a conduit of its speaker's communication culture.

The above phenomenon raises the importance issue of awareness in intercultural communication within the business interaction conducted by BELF speakers. The Interaction is mainly targeted to maintain relationships and establish rapport between BELF interactants. Mutual understanding and compromise often becomes a base in encountering business discourse so that they can establish positive perspective on business not just on competitive transactional activity but also as a collaborative, and ultimately relational, human undertaking (Planken \& Nickerson, 2009, p. 120). In detail Spencer-Oatey (cited in Planken \& Nickerson, 2009, p.118) say that rapport needs to be managed across five interrelated, but discrete, domains of interaction. Those five are; 
1. the illocutionary domain (the performance of speech acts),

2. the discourse content domain (e.g. choice of topic, structure and sequencing).

3. the participation domain (e.g. turn-taking, inclusion or exclusion of partipants, back-chanelling),

4. the stylistic domain (e.g., choice of tone, formality level, register), and

5. the non-verbal domain (e.g., gaze, posture, gestures).

In order to succeed in building up the rapport, the BELF speakers should consider these five domains from the bi-polar perspective, shared understanding of cultures in respect to the respective cultural background of the BELF speakers.

Building up rapport in business communication is pertinent, particularly in dealing with conflictive setting such as negotiations. Planken and Nickerson identify two aspects of building rapport across culture in the BELF setting, i.e. through the use of "safe talk" and personal pronouns. Being able to determine right form of safe talk and personal pronoun is crucial as it may lead into either success or failure of the negotiations.

Eventually, Poccini (2004) as cited in Planken and Nickerson (2009) sums up that intercultural communication concentrates on three salient linguistic features of BELF. First, it is related to the use of personal pronoun. BELF speakers use this pronoun in order to switch roles, build identities, and shift allegiance during the business meetings and within the company. Second, it is in regard to the use of specialized lexis. Poccini reports that specialized lexis works to reflect and construct the social roles participants play in the company and at meetings, to frame the business activities undertaken. And third, it is related to the use of evaluative lexis, which is commonly used to strategically accomplish tasks such as image-building, pre-empting criticism, building positive connotations, managing participation, and construing roles.

\section{GLOCALIZED ENGLISH IN ADVERTISEMENTS}

Advertisement cannot be separated from people in day to day life. Almost every second, people are exposed before them many types of advertisement either from TV, poster, leaflet, newspaper, magazines, radios, and other communication channels. Through the use of persuasive language these advertisements sway people to do or buy things they advertise.

English is commonly used to advertise the global market products. Within the local marketing context, that is particularly either in outer circle or expanding circle countries (Kachru \& Nelson, 2001), English advertisements have relatively distinctive features compare 
to those in the inner circle countries. It is almost axiomatic to say that one can only sell in the customer's language (Nair-Venugopal, 2008, p.55). Therefore, in the local context English advertisements usually adapt local language use such as speaking in the local idiom and using local accent. Incorporating knowledge of the local practices, values and norms -dubbed 'local knowledge' - into the advertisement content also often facilitates the sales.

Unlike BE used to survive in the multicultural business interactions or business meetings, the use of English in local advertisement has its peculiar characteristics, particularly in building rapport with the target audience. While the former tend to focus on playing with features such as personal pronoun, specific lexis, and evaluative lexis, English in advertisements tend to establish rapport with consumers through the accommodation of local values and knowledge which are expressed within the English use. Besides, it also deliberately adopts the local language features, such as intonation, accent, and dialect.

The intercultural aspect of communication in glocalized English is marked by the notion of 'cosmopolitanism' and 'neutrality' (Nair-Venugopal, 2008, p.58). She explains that 'cosmopolitanism' refers to worldiness, such as in citizenship of the world, and (by extension) to an appreciation or consideration for cultures besides one's own. On the other hand, 'neutrality' refers to the balance achieved between heterogeneity and homogeneity as two contradictory forces if globalization or globalism is taken to be an axial phenomenon in relation to that of localization or localism. These phenomena can be understood as the genuine social purpose of advertisement is to persuade people to do or to buy things; therefore, establishing closed relationship and image of impartiality of knowledge, identity and perspective is prominent. Creating image that the products are parts of the property which support local culture is relatively essential, and therefore the advertisement language accommodate the values of local cultures.

\section{E. IMPLICATION IN ESBP TEACHING}

Studies on intercultural issues within BELF and glocalised English not only benefit the business enterprise side where those two types of English are used between speakers that represent different cultures and contexts, however they also have a number of potential implications for ESBP pedagogy, specifically where BELF and glocalized English are concerned.

Planken and Nickerson (2009) say that the notion of BELF as a shared, highly functional code needs to be balanced against the fact that BELF users will still incorporate 


\section{JURNAL NOMINAL / VOLUME II NOMOR I / TAHUN 2013}

their own, not necessarily shared, mother tongue patterns, culture(s), and culturally determined convention and practices within the BELF discourse. This notion brings implication that in teaching learners to use BE around the world, the BELF perspective should always be foregrounded. Leaners need to be trained first and foremost 'to see themselves as communicators who have real jobs to do and needs to fulfil'; as a result, it is 'these jobs and needs that should be emphasized in courses, not the language they use to carry them out' (Louhiala-Salminen et al. (2005) as cited in Plaken \& Nickerson, 2009).

It is discussed above that the use of BELF within the business interaction may bring potentiality of the speakers to bring with them their cultural values, beliefs, and norms which are represented in their BELF interactions. In regards to this potential chance, LouhialaSalminen et al. suggest that in BESP course, learners need to be made aware of "how to use contextual clues" and to organize the "situational presuppositions" of their counterparts in an interaction. Being aware of these features and make the most use of them will facilitate the communication, and hence increase the mutual intelligibility between business counterparts. Besides, Planken \& Nickerson also suggest that training listening skills should be highlighted in this course so that learners will be accustomed to comprehending business interaction communication for which they need to get fully-aware of what the interactants say and imply within their expressions.

In response to the evidence of glocalized English, it implies the need of building understanding and awareness of world Englishes in the learners' mind. The idea that ownership of English is relatively fuzzy should be made clear, and therefore learners will build up positive attitudes in perceiving the English variety they learn in BESP. It is not the idea of accuracy which marks the communication success in Business English but rather to what extent speakers are able to take an appropriate stance in facing and handling the business affairs they are taking part. Being flexible and being able to compromise with other cultures need to be developed by learners as this quality is a pre-requisite to survive in today's rapidly changing, unpredictable, global business community (Planken \& Nickerson, 2009, p.117).

\section{F. CONCLUSION}

Language and culture is like two sides of the same coin. It cannot be separated from each other. Therefore when one start to learn a language they will also learn the culture bounded to that language. In the ESBP area, intercultural communication is likely to be common phenomena, particularly in the multiparty/multicultural business setting. This setting 
often indicates the fact that fellow working partners are from different cultural backgrounds. Therefore, they may share different beliefs, values, norms, and ways of communication during the interaction.

The fact that in business discourse, language serves as a tool to get the work or business done characterize the specificity of the English use within the area. English in this field often functions as a lingua franca. By this, the successfulness of business communication is often perceived when the speakers can get their message across to their respective interactants and when there is a mutual intelligibility between the speakers.

Besides the BELF phenomenon, intercultural communication in business English is also marked with the emergerce of glocal English. This glocal English can be found mostly in the outer circle or expanding circle countries, where there is adaption towards the English used in the local context. In the business setting, this glocal English often widely found in the commercial advertisements.

The emergence of BELF and glocal English as the result of cultural contact leads to concern into BESP pedagogy. Appropriate approach, teaching technique and method, materials need to accommodate these phenomena in order to achieve the better result of learning process. Learners need to be made aware that business English is dynamic and rich in terms of cultural values, and therefore asking them to simulate encountering business interaction might give valuable experience in their learning process.

\section{G. REFERENCES}

Bargiella-Chiappini, F. (2005). Asian business discourse(s): An introduction. Journal of Asian Pacific Communication, 15(2), 207-228.

Bargiella-Chiappini, F., Nickerson, C., and Planken, B. (2007). Business discourse. Hampshire: Palgrave Macmillan.

Bondi, Marina. (2004). "If you think this sounds very complicated, you are correct": Awareness of cultural difference in specialized discourse. In C.N. Candlin \& Maurizio Gotti (Eds), Intercultural aspects of specialized communication, (pp. 5378). Oxford: Peter Lang.

Brown, H.D. (1992). Sociocultural facors in teaching language minority students. In Patricia A. Richard-Amato and Marguerite Ann Snow (Eds.), The multicultural classroom: reading for content-area teachers (pp. 73-92). New York: Longman 
Kachru, B.B. \& Nelson, C.L. (2001). World Englishes. In Anne Burns and Caroline Coffin (Eds.), Analysing English in a global context, a reader (pp. 9-25). London: Routledge.

Louhiala-Salminen, L., Charles, M., \& Kankaanranta, A. (2005). English as a lingua franca in Nordic corporate mergers: Two case companies. English for Specific Purposes, 24, 401-421

Nair-Venugopal, Shanta. (2008). Appropriating English as the world's local language of global communication. ESP Across Cultures, 4, 66-79.

Nelson, M. (2000). A corpus-based study of the lexis of business English and business English teaching materials. Unpublished thesis. University of Manchester. Manchester. Retrieved from http://users.utu.fi/micnel/thesis.html. on May 9th, 2012.

Planken, B. and Nickerson, C. (2009). English for specific business purposes: Intercultural issues and the use of business English as lingua franca. In Diane Belcher (Ed.), English for specific purposes in theory and practice (pp. 107-126). Ann Arbor: University of Michigan Press.

Warren, Martin. (2008). An initial corpus-driven analysis of the language of call centre operations and customers. ESP Across Cultures, 4, 80-100. 